\title{
Community-Based Arts and Participatory Act: Inclusive Knowledge as Intangible Culture Heritage Empowerment (ICHE)
}

\author{
Diana Ibrahim, MohdYuszaidyMohdYusoff, YusmilayatiYunos, RosliZakaria, \\ MohdSaharuddin
}

\begin{abstract}
Intangible Culture Heritage (ICH) exists through collectively cultured actions and is identified individually, in groups and large divisions or communities. The weight of modernization that necessitates reform in all facets of life has threatened the practice and compromised the tradition of cultural comprising the intangible cultural heritage of current society. This study aspires to examine the mechanism of activities based on ICH in a community-based art project Lendu International Art Camp (LIAC). The qualitative study in the mode of this single case research concerned observation, fieldwork and document analysis. The study discovered that Intangible Culture Heritage Empowerment (ICHE) appeared through the value of inclusive knowledge/education built through three groups of activity classifications encompassing; Visual Art Expression, Health \& Wellbeing and Heritage \& Local Culture. This usefulness of inclusive knowledge/education has a diversity of styles of learning pedagogy such as collaborative, collective, informal and experiential learning that is established from the participatory action of the participants. The contributions of this research are that community-based art bears the potential to be a substantial contributor to reviving the cultural heritage of the community by way of comprehensive, inclusive knowledge.
\end{abstract}

Keywords: Community-based art, education, inclusive knowledge, intangible culture heritage empowerment, participatory act.

\section{INTRODUCTION}

Intangible cultural heritage has faced dangers of decline, loss, erosion and dwindle as an impact of modernization and social transformation that has influenced the global humankind - realizing the essential of executing the conservation and preservation of this heritage, the UNESCO body at its convention on July 17, 2003 instituted guidelines as an initiative to preserve and maintain the sustainability of intangible culture similarly with discernible and natural heritage. As being maintained by UNESCO's definition,

Revised Manuscript Received on September 14, 2019.

Diana Ibrahim*,Malay Excellence and Sustainable Heritage, Faculty of Social Science and Humanities, National University of Malaysia, 43600 Bangi, Selangor, Malaysia \& Faculty of Art and Design, Universiti Teknologi MARA, 78000 Alor Gajah, Melaka, Malaysia. (E-mail: dianaibrahim001@gmail.com)

Mohd Yuszaidy Mohd Yusoff, Malay Excellence and Sustainable Heritage, Faculty of Social Science and Humanities, National University of Malaysia, 43600 Bangi, Selangor, Malaysia. (Email: yuszaidy@ukm.edu.my)

Yusmilayati Yunos, Malay Excellence and Sustainable Heritage, Faculty of Social Science and Humanities, National University of Malaysia, 43600 Bangi, Selangor, Malaysia. (Email: yusmila@ukm.edu.my)

Rosli Zakaria*, Faculty of Art and Design, Universiti Teknologi MARA, 78000 Alor Gajah, Melaka, Malaysia. (E-mail: roslizakaria@yahoo.com)

Mohd Saharuddin Supah@Supar, Faculty of Art and Design, Universiti Teknologi MARA, 78000 Alor Gajah, Melaka, Malaysia. (Email: saharsupar@gmail.com). manifestations of intangible cultural heritage includes domains such as oral expressions (languages), artistic expressions of performances, rituals (religious) or festivals and social practices exercised within a group of people, knowledge and practices associated to the universe as well as handmade products such as traditional crafts [1]. The domain is neither standard nor equivalent; it is analyzed distinctively by the cast, ethnic, race or community based on the practices that emerge within the group.

In Malaysia, among the attempts of the government to protect intangible cultural heritage from being neglected, ignored and claimed by other countries, the enactment of the National Heritage Act 2005 (Act 645) has been established to preserve the country's heritage treasures. Intangible cultural heritage is classified into two categories: heritage and national heritage comprising food, clothing, customs, dance and songs such as rasa sayang and traditional music [2]. This intangible cultural heritage represents pride and identity, possessed and inherited through the ethnic diversity of the indigenous people of Malaysia and immigrant communities such as the Chinese and later Indian. This legacy covers living cultures or practices and cultural objects that are introduced together and collectively, specifically individually, as a group or in large circles or communities.

Apart from the imposition of the law and the ratification of heritage protection laws, UNESCO also elevates empowerment to inaugurate an exceptional appreciation among the community, especially the younger generation, about the significance of preserving and protecting intangible cultural heritage. The medium proposed as one of the platforms to facilitate the protection of cultural and the preservation of intangible cultural heritage is through education [2]. The educational medium, as being mentioned by [1], is a considerable potential medium for the spreading of knowledge-based channels of cultural heritage and promotes the sustainability of practice among communities. According to [3] also propounded the development of knowledge and education through a community-based arts program based on local cultural activities can function as a medium of conservation on cultural heritage and can prompt multiple benefits of social well-being to the community.

Nevertheless, the advantage in the context of educational value and knowledge that is aspired to be created depends on the nature of activity mechanism and audience/ 


\section{COMMUNITY-BASED ARTS AND PARTICIPATORY ACT: INCLUSIVE KNOWLEDGE AS INTANGIBLE CULTURE HERITAGE EMPOWERMENT (ICHE)}

community's participation of in the activity. Audience participation in community-based arts activities has become a vital basis since it works to indicate the value of the benefits that come from participating in the arts.

Ergo, a case study based on the Lendu International Art Camp (LIAC) community-based program was completed to identify participatory mechanisms in modes of art that emerged in art activities that had notable cultural heritage value with goals of exposing the value of inclusive knowledge/education based on participatory audience level on the art activities concerned.

\section{THEORY PLATFORM}

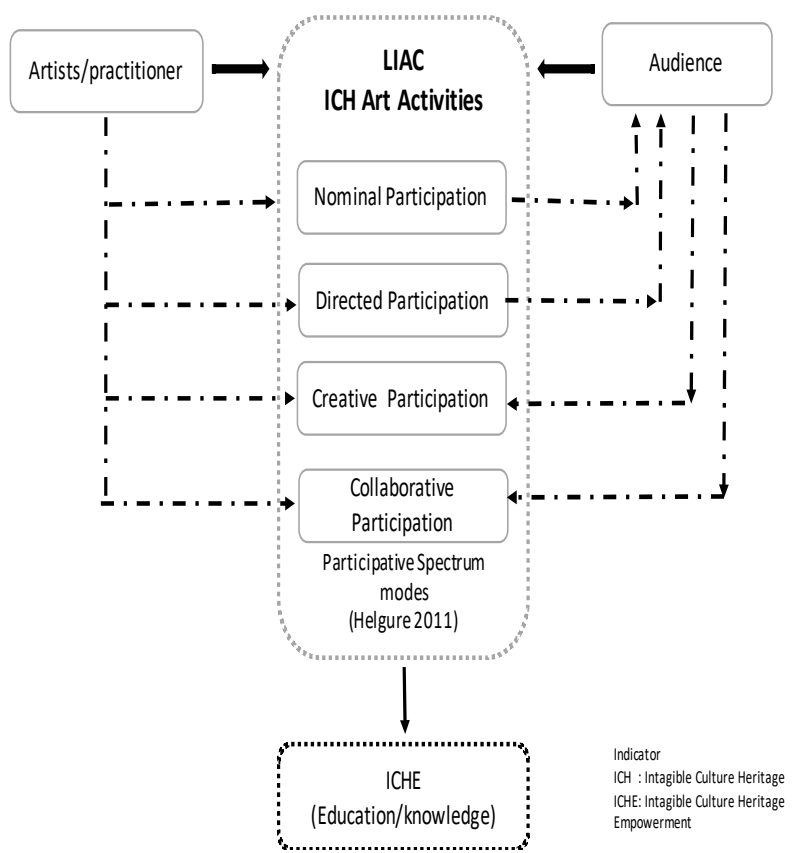

Fig. 1.Analysis framework in LIAC Intangible Culture Heritage ( $\mathrm{ICH})$ art activities.

Fig. 1 is an illustration of the research framework produced in this paper comprising the analysis of participatory behaviors that emerge in each ICH-based activity in the LIAC art project. An evaluation of participatory audience behavior is based on a participatory theory in the aesthetics of art as a social activity; Social Engage Art (SEA).

According to [4] affirms that SEA participatory theory is a hybrid aesthetic of art between artistic and non-artistic activities by involving symbolic acts that promote participatory participation among the participants. The interaction of social relations symbolically forms art through artists working with the audience, creating an environment that motivates a new experience of the community through art objects.

Based on this theory, Helgure mentions that participatory audience behavior can be classified into several levels. The first level of 'Nominal participation' (NoP) covers very minimal participant participation by the audience/participants related. Audiences work as product recipients / creative products made by artists. Participants in this level are classified to be inactive receptors as there is no involvement in the process of creative behavior.

The second level of 'Directed participation' (DrP) encompasses participatory behaviors that instigate the creativity of artists/ others. At this level, the audience is completely guided in the creative process of the artistic activity created by the artist. It is at this stage, too, the audience is grouped as an averagely active receptor following the existence of a creative process steered by the artist.

While, the third level concerns a participatory act entitled 'Creative participation' (CrP) by attracting the participants/audience in completing of the creative process with very little tips or direction from the artist/another person. During this level, the audience is labeled as an active receptor due to the presence of a creative process that is dominantly maneuvered by the audience.

The last participant spectrum is namely 'Collaborative participation' (ColP). This spectrum brings a collective work culture dimension, in which participants share the task for conducting an activity made by developing their ideas and their work/activity cooperatively. At this level, the audience is classified as the most active receptor. It is followed by the existence of a collaborative process that is co-administered between the audience and the artist.

In this analysis, gauging participatory audience engagement on activities within the LIAC Intangible Culture Heritage (ICH) developed by artists is pivotal to ascertain what knowledge/education values are emerging. Hence, in this study, the evaluation of participatory audiences is a key basis for discovering the success of Intangible Culture Heritage Empowerment (ICHE).

\section{METHODOLOGY}

This study exploits a qualitative approach based on a single case study form. The approach of the case study is selected following a more specific focus on the forms of activities made by the artist can be examined more critically and in-depth. This single case study concerned a community art project based on the Lendu International Art Camp (LIAC), which was carried out by a group of artists named ArtisGomen.

This research entailed the method of observation of emik and etik that is observation and participation. This step has been carried out by authors in all three series of LIAC community-based art projects ranging from pre-festival activities (held before the actual day of the festival) to threeday festival activities. Document analysis is too done with reviews acquired through printed material such as catalogs, books as well as pictures and video recordings of the activities completed.

\section{RESULTS AND ANALYSIS}

Lendu International Art Camp (LIAC) is an art event held in 2013, 2014 and 2016 in the village of Dun Lendu located in the Alor Gajah area of Malacca. The organization drawn in the Malay village of Lendu initially and attracted two other villages (Durian Daun and Durian Daun Barat villages) in its third series in 2016. The art project was prompted and carried out by the collective group of ArtisGomen through a network of multiple collaborative networks between the UniversitiTeknologi MARA

Published By:
Blue Eyes Intelligence Engineering

\& Sciences Publication 
(Melaka), the National Art Hall of Malaysia, the State Art Museum of Malacca, Malaysia, the local arts association and the Village Safety and Joyfulness Committee (JKKK).

Table- I: LIAC 2013-2016 art activities

\begin{tabular}{|c|c|c|}
\hline Category & $\begin{array}{l}\text { Program/Ye } \\
\text { ar }\end{array}$ & Form of Activities \\
\hline \multirow{4}{*}{$\begin{array}{l}\text { Visual } \\
\text { Art } \\
\text { Expressio } \\
\text { n (VAE) }\end{array}$} & LIAC 2013 & $\begin{array}{l}\text { Murals paintings } \\
\text { Street arts } \\
\text { Environmental art } \\
\text { Life-Drawings } \\
\text { Pasar Karat } \\
\text { DondangSayang (PKDS } \\
\text { Bundle) } \\
\text { Performing arts: } \\
\text { Instrumental Music } \\
\text { Short film Screening } \\
\text { show: TanjungRambutan } \\
\text { Art talk } \\
\text { Art forum } \\
\text { Art exhibition }\end{array}$ \\
\hline & $\begin{array}{l}\text { Pre-LIAC } \\
2014\end{array}$ & $\begin{array}{l}\text { Signage Arts } \\
\text { Soft sculpture }\end{array}$ \\
\hline & LIAC 2014 & $\begin{array}{l}\text { Flag Banner paintings } \\
\text { Murals paintings } \\
\text { Life-Drawings } \\
\text { Performing arts: } \\
\text { Random Access Memory } \\
\text { (RAM) } \\
\text { Pasar } \\
\text { DondangSayang (PKDS- } \\
\text { ABC) } \\
\text { Art forum } \\
\text { Art exhibition }\end{array}$ \\
\hline & LIAC 2016 & $\begin{array}{l}\text { Mural paintings } \\
\text { Vector Drawings } \\
\text { Photo-shoot }\end{array}$ \\
\hline \multirow{3}{*}{$\begin{array}{l}\text { Health \& } \\
\text { Wellbeing } \\
\text { (H\&Wb) }\end{array}$} & $\begin{array}{l}\quad \text { Pre-LIAC } \\
2013 / 2014 / 201 \\
6\end{array}$ & $\begin{array}{l}\text { Communal work: } \\
\text { Gotongroyong } \\
\text { Communal work: } \\
\text { Musawarah (Meeting) }\end{array}$ \\
\hline & LIAC 2014 & $\begin{array}{l}\text { Communal work: } \\
\text { KenduriSeni }\end{array}$ \\
\hline & LIAC 2016 & $\begin{array}{l}\text { Free Hair cut } \\
\text { Aerobics } \\
\text { Health Screening }\end{array}$ \\
\hline \multirow[b]{2}{*}{$\begin{array}{l}\text { Heritage } \\
\& \quad \text { Local } \\
\text { Culture } \\
\text { (H\&LC) }\end{array}$} & $\begin{array}{l}\text { Pre-LIAC } \\
2014\end{array}$ & $\begin{array}{l}\text { Traditional craft: Rattan } \\
\text { wicker }\end{array}$ \\
\hline & $\begin{array}{l}\text { LIAC } 2014 \\
\text { LIAC } 2016\end{array}$ & $\begin{array}{lc}\text { Traditional music: } \\
\text { DondangSayang } \\
\text { Traditional craft: } \\
\text { Bamboos tube savings } \\
\text { Traditional food: } \\
\text { Ketupat } \\
\text { Traditional } \\
\text { Lemang food: } \\
\text { Traditional } \\
\text { Kompang }\end{array}$ \\
\hline $\begin{array}{l}\quad \text { Economi } \\
\text { c } \\
\text { Empowerm } \\
\end{array}$ & LIAC 2016 & $\begin{array}{l}\text { Chili fetergation } \\
\text { planting } \\
\text { T-shirt printing } \\
\end{array}$ \\
\hline
\end{tabular}

Table I encapsulates the activities done in the first to third series of the LIAC program with a sum of 40 activities. These activities have been classified into four categories; Visual Art Expression (VAE), Health \& Wellbeing (H $\& W b)$, Heritage \& Local Culture (H\&LC) and Economic Empowerment (EE). There were 22 activities under VAE category, 10 activities under $\mathrm{H} \& \mathrm{~Wb}$ category, six activities under H\&LC category and two activities under EE category.

The whole program unites a comprehensive range of participants covering local and international physical arts activists, cultural arts activists, art academics, art students from public and private universities, students and locals in the Dun Lendu area. The creation of program themes such as Village Art (first version of LIAC2013), Village Art Festival (second version of LIAC2014) and Village Art: Preserving the Green Tradition (third version of LIAC2016) has been proposed as a base for artists in planning and forming activities executed in two phases, namely phases before and during the program.

The outcomes of the analysis of the various activities done in LIAC discovered that some activities that offered important cultural heritage significance were successfully recognized under the $\mathrm{VAE}, \mathrm{H} \& \mathrm{~Wb}$ and $\mathrm{H} \& \mathrm{LC}$ classifications. A more thorough summary of activities comprising intangible cultural heritage and participatory forms will be conferred through the analysis in Fig. 2 to 4 as below.

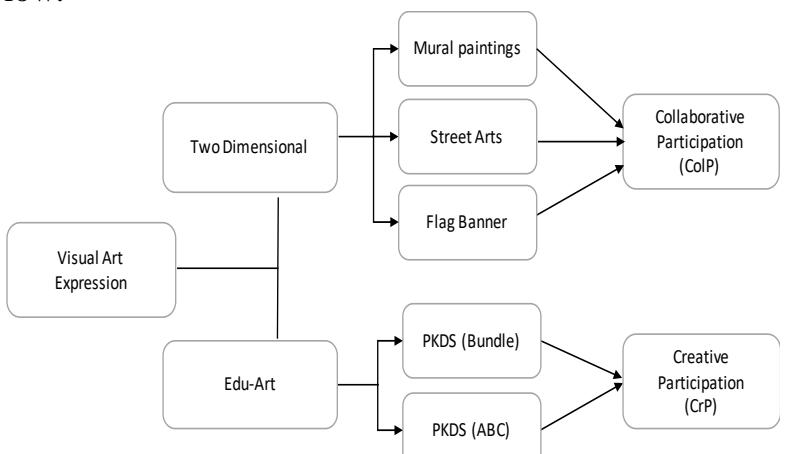

Fig. 2. Breakdown of ICH activity under the category 'Visual Art Expression'

Referring to Fig. 2, there are only five art activities under the VAE group that are acknowledged as carrying the value of for Intangible Cultural Heritage Empowerment (ICHE). Activities that come to this category are split into two subcategories; Two Dimensional Participative practice art and Edu-Art. For the Two Dimensional Participative subcategories, this art form covers three activities specifically; murals paintings, street art paintings and Flag Banner paintings.

The mechanism of activities performed under the Two Dimensional Participative subgroup calls for participants to visualize the visual data that present around them and translate it into their work. The subject or even the images that sketched/formed are generally impromptu ideas that are produced, while the participants are at the village location. Some of the subjects covered take into account traditional food images such nasilemak, ketupat, sate, local cakes such

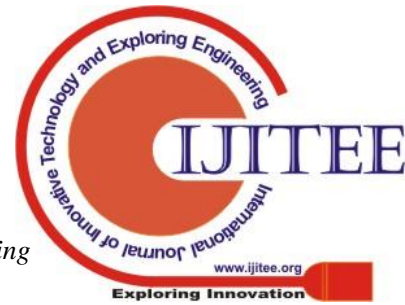




\section{COMMUNITY-BASED ARTS AND PARTICIPATORY ACT: INCLUSIVE KNOWLEDGE AS INTANGIBLE CULTURE HERITAGE EMPOWERMENT (ICHE)}

ascurrypuff, kuihbakar. Traditional games like teng-teng, dam haji and moon kite. Traditional crafts such aslabusayong, mangkuksia (Baba and Nyonya tiffin). Traditional musical instruments such as gambus. Traditional oral literature such as poetry, khat calligraphy, trishaw, as well as sketches of village houses such as the Malacca staircase.

Through these activities, participatory behaviors that appear are classified as Collaborative Participation (ColP), which covers participants establishing their ideas and working jointly without specific guidance. Participants work together on matters of subject selection, drawing and coloring processes on different surfaces be it on the shop wall, on paved roads and banners such as 6-foot-long ones. The ICHE's effort materializes when these works exhibited/positioned in open spaces in the vicinity of the village, particularly in the town of Lendu village. The signifies that this activity implicitly not only contributes ICH-related knowledge to the participants concerned, but it, too, works as a medium of disseminating knowledge immediately to the audience when it is in the public space.

While, the second category is an Edu-Art artwork that involves activities such as the Bundle versions of Pasar Karat DondangSayang (PKDS) and Air BatuCampur $(\mathrm{ABC})$. As being maintained by [5], this mode of art engages three elements; Performance, Installation and Education (PIE) are assimilated throughout the whole activity. 'Performance' here refers to the participatory component that is present when the audience participates in the held activities. 'Installation' refers to the object exercised in work to entice the audience to participate, whereas 'education' is a known value in the art of drawing the audience when they take part in the activity.

The 'Participative-Installation' - PIE model is a mechanism of practice in this PKDS activity that entails the public invited to create a sketch, which is then exchanged for products such as clothing, toys and some other items, contributed by ArtisGomen. The title of the Pasar Karat activity itself hints at an activity related to the sale of goods based on the bundle basis, which is still in excellent condition. The sale of used items is a great local community practice in specific locations in Malaysia such as Loken Ipoh Market, Perak, Market, Johor, Rope Walk @ Penang Flea Market, Penang and some places in major cities such as Kuala Lumpur, Malacca, Shah Alam and Seremban.

While, the PKDS version of (ABC) is a signature dessert generally found at food and beverage stalls in the 80 s and 90 s, both in villages and in urban areas. Vital elements to be highlighted in the installation work placed in this public space cover the design of a traditional Malay transport stall, including of keretalembu, traditional ice grinding tools and local dessert ingredients.

Both of these PKDS activities go on to engage the participatory audience in generating creative works independently, leading to the participatory nature of 'Creative Participation' (CrP). This is because the mechanism of action necessitates the audience to take total maneuver of the art production process. It is interesting that through these two events, the weight of the cultural heritage can be uniquely symbolized by the ArtisGomen when it is adopted as an intermediary to unveil potential or artistic talent (creativity) among the participants, namely the audience who does not have the talent to draw. This process, as being maintained by [6] can promote the audience to be at the highest level named 'Audience-As-Artist' when the artistic experience is completely administered by the audience. This PKDS activity works as an ICHE agent following the local elements (objects) that are featured in this participatory activity process.

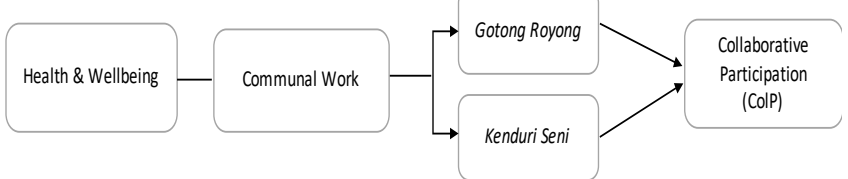

Fig. 3. ICH activity breakdown under the category 'Health \& Well Being'

The LIAC program too, encourages activities based on local social execution such as good neighborhood practices that fall under the category of 'Health \& Well Being'. Activities under this category concern ten activities held in all three series of LIAC projects. Nonetheless, only two activities have been noted that bear the potential for Intangible Culture Heritage Empowerment (ICHE), through activities that are categorized as good neighborhood practices. Fig. 3 offers the breakdown of activities and participatory mechanisms that exist through these communal work activities.

Both activities were categorized as communal work as they motivated the initiatives to create a network of social ties among locals and outsiders. The effort was carried out through the gotongroyong activity project, which concerned cleaning the village and kenduri cooking projects. The realistic mechanism of its involvement is to display ColP's participatory form of attracting the community of villagers with organizers (ArtisGomen) and LIAC program participants.

Both of these intangible cultural heritages (gotongroyong and kenduri activities) have a value or ethos that is nature or characteristic that binds them together in community life in the Malay realm. The value or ethos of this traditional Malay society, in the opinion of [7] is based on principles such as unity, kinship, cooperation, helping each other, equality, loyalty, integrity and shame. As proposed by him, this execution has started to decline as a result of modernization. Currently, this excellent neighborhood system has faded in community life in some places, particularly in urban areas. LIAC revitalizes good neighborhood practice through both communal work activities.

Apart from reintroducing the two values of deteriorating intangible cultural heritage, its practical mechanism indirectly creates another value added by creating new relationships among local communities with outsiders. The worth of this new relationship is proposed by [8] as one of the indicators of promoting expansion in the benefit of social unity among LIAC participants. Constituting the value of new relationships through daily social activities, expressed by [9], that in the 
'relational aesthetics' that art execution is in the atmosphere of everyday habits and is not restricted to definitive spaces (galleries and art museums).

Through the mechanism of such activity, art is perceived as an experience, rather than a pure object.

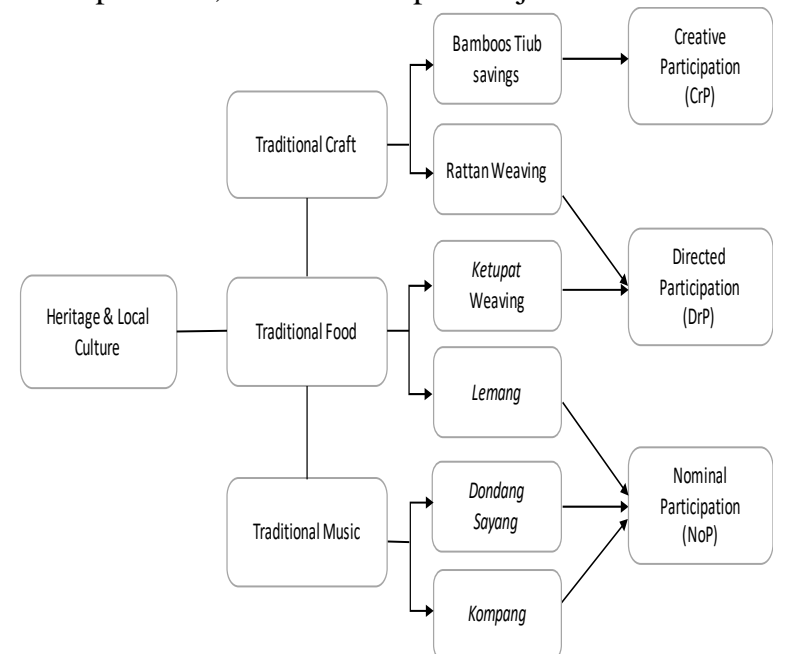

Fig. 4. Breakdown of ICH activity under the category 'Heritage \& Local Culture'

While the third category, Heritage \& Local Culture, it includes six activities held in the three series of LIAC projects, all of which have a tendency for empowerment on intangible cultural heritage. Referring to the small fractions in Fig. 4, this cultural heritage empowerment activity is separated into three groups; craft arts, eating local food and traditional music.

The mechanism of custom in activities based on traditional craft (rattan weaving) and traditional food (ketupat weaving) includes the process of 'skill transfer'. The process comprised sharing the knowledge and skills of the villagers as well as artists related to food heritage and the manufacture of handicraft objects directly by the locals to the participants. Referring to the participation spectrum under the SEA, participants' engagement in these activities is classified as 'Directed Participation' (DrP). This is because the audience is fully guided in the production process and does not add new value to the object being made.

Whereas, traditional crafts (bamboo tubes) calls for the process of developing participants' creativity through the process of carving and designing decorative patterns on bamboo tubes. The mechanism of bamboo tube activity implies minimal supervision by the artist on the participants. Hence, a participatory style seems to be in the category of 'Creative Participation' (CrP). Through this research, the researcher unveiled that the three activities (rattan weaving, ketupat weaving and bamboo tubes) required the process of observation, reflective thinking and participatory behavior in group mode. It is in this context that the process of communication of the participants becomes a fundamental agent in the operation of enhancing ICHE through the knowledge acquired.

While, traditional food activities (Lemang) are sorted as 'Nominal Participation' (NoP) due to the absence of creativity produced by the audience through this event, similarly, it can be observed in the traditional musical performances of the musical DondangSayangand Kompang. Both activities comprise performing arts that are participated by the villagers as a group. The mechanism of practice grows the nature of one-way communication; the participatory process of the activity being held is less highlighted.

This mechanism carries little contribution to encouraging the value-added (knowledge/skills) of the audience. According to the report of [6], in the context of performing arts, audiences that recognize only the final product of a work of art are grouped as 'receptive audiences.' 'Receptive audience' is divided into two categories; First, they are positioned out of the participatory boundary when the audience is engaged as a sole observer/art lover. Second, the audience can be regarded as passive if the activity can move the creative thinking, but not the creative expression of the participants.

This traditional music art activity proves that participants are in the NoP classification as the audience is in the first category of 'receptive audience'. Knowledge value is minimized in both activities. Furthermore, for the traditional music art category, this intangible legacy of cultural empowerment could not reach its maximum, in comparison to the traditional food and craft heritage categories. Ergo, this is a slight impediment to ICHE's efforts on traditional music art.

To conclude, this analysis proved that the LIAC community-oriented arts program developed local cultural heritage (ICHE) empowerment through three main elements of the activity; Visual Art Expression, Heritage \& Local Culture together with Health \& Wellbeing. The activities are partially based on the context of the local community, containing the practices, culture and values of the traditional Malay community and others are based on the arts activities in the performing arts. Through the analysis of the practical mechanisms for these three groups of activities it is evident that the empowerment of cultural heritage is not significantly represented through:

i. Visual Art Expression category; through images (subjects) sketched by participants in drawing and painting based activities.

ii. Heritage \& Local Culture categories; through legacy-based activities, which concern skills acquired.

iii. Health \& Well Being; through activities that contain social work by promoting excellent neighborhood practices within traditional Malay community groups.

Each of these activities offers an array of mechanisms as well as participatory behaviors among participants. The mechanism of activity produced by artists and organizers will impact the active participatory action that leads to the process of empowerment over the intangible cultural heritage of the LIAC art project. 

CULTURE HERITAGE EMPOWERMENT (ICHE)

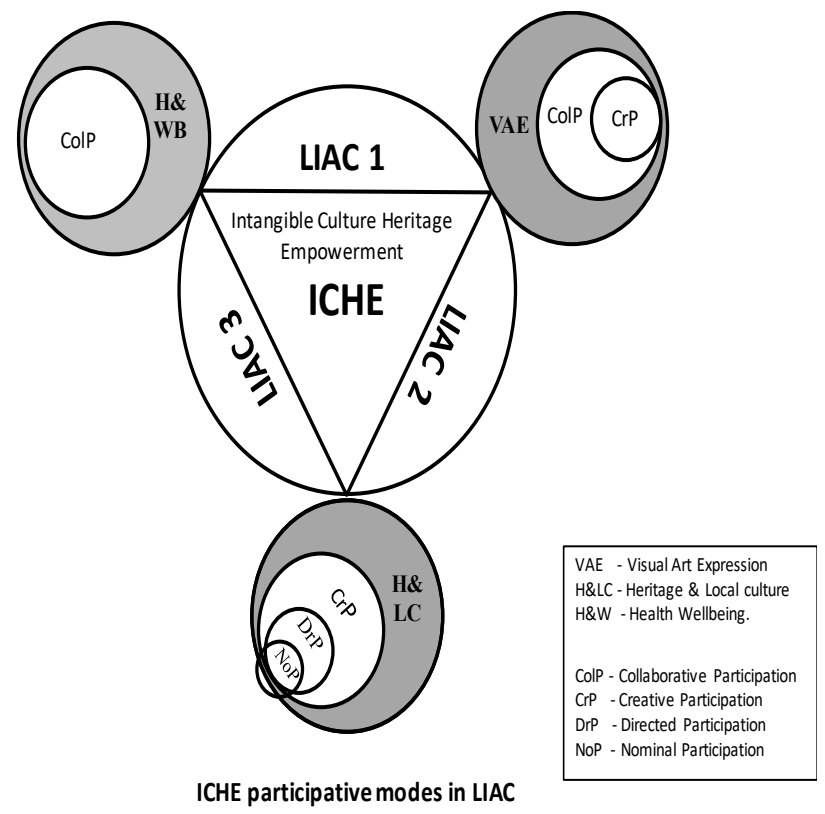

Fig. 5. Participatory forms appearing through ICHE in LIAC.

Generally, a participatory mode that appears through this Intangible Culture Heritage Empowerment (ICHE) activity is showcased through Fig. 5. For the VAE category, two manifestations of participatory action on effect took place among participants concerning ColP and CrP participants. For this classification, participants in the form of ColP were more dominant than participants in the form of $\mathrm{CrP}$.

Meanwhile, the classification of activity under the H\&LC group concerns three participatory forms, monopolized by the participatory form of $\mathrm{CrP}$, followed by $\mathrm{DrP}$ and NoP. Through the H\&LC category, refer to the illustration of Fig. 5. Participatory actions classified as NoPs are somewhat out of the circle of H\&LC. It is because the participatory nature of the project does not promote the process of creativity among the audience. Hence, it impacts the worth of knowledge formed as an initiative to empower the intangible cultural heritage.

Conversely, there are diverse categorizations of activity under the $\mathrm{H} \& \mathrm{~Wb}$ group, where only one participant form that is ColP. The participatory behaviour that arose was governed by its mechanism of 'socio-cultural practice' based on excellent neighbourhood customs, which are substantially rooted in the context of traditional Malay society. The mechanism by which this form of art can precisely energize the lost cultural heritage is disappearing in this very day's modernization.

\section{DISCUSSION}

Through the analysis administered, the results of this research proved that Intangible Culture Heritage Empowerment (ICHE) in LIAC art projects is underpinned by the form of audience participation that arises in each of its activities. The participatory spectrum that is created will affect the value of Intangible Culture Heritage Empowerment (ICHE) in the knowledge/education context created through ICH-based activities.
Table- II: Learning gain in LIAC ICH art activities

\begin{tabular}{|c|c|c|c|}
\hline $\begin{array}{l}\text { Participatio } \\
\text { n Modes }\end{array}$ & $\begin{array}{l}\text { ICH } \\
\text { Activiti } \\
\text { es }\end{array}$ & $\begin{array}{l}\text { Education/Knowledg } \\
\text { e Gain }\end{array}$ & $\begin{array}{l}\text { Pedagogica } \\
\text { I Learning }\end{array}$ \\
\hline \multirow[t]{2}{*}{ Colp } & $\mathrm{H} \& \mathrm{~Wb}$ & $\begin{array}{l}\text { Develop the value of } \\
\text { moral education } \\
\text { (value of cooperation, } \\
\text { mutual assistance and } \\
\text { mutual understanding) } \\
\text { among participants } \\
\text { based on "Socio- } \\
\text { cultural practice" } \\
\text { activities. }\end{array}$ & \multirow[t]{2}{*}{$\begin{array}{l}\text { Collaborativ } \\
\text { e learning }\end{array}$} \\
\hline & VAE. & $\begin{array}{l}\text { Foster knowledge } \\
\text { through visual themes } \\
\text { (paintings) of local } \\
\text { heritage and culture. }\end{array}$ & \\
\hline $\mathrm{CrP}$ & $\begin{array}{l}\text { VAE } \\
\text { and } \\
\text { H\&LC }\end{array}$ & $\begin{array}{l}\text { Developing education } \\
\text { informally through } \\
\text { the process of } \\
\text { creativity. }\end{array}$ & $\begin{array}{l}\text { Informal } \\
\text { learning }\end{array}$ \\
\hline DrP & H\&LC & $\begin{array}{l}\text { Develop education } \\
\text { and skills directly to } \\
\text { the audience through } \\
\text { skilled practitioners } \\
\text { (artists/artists). }\end{array}$ & $\begin{array}{l}\text { Collective } \\
\text { learning }\end{array}$ \\
\hline $\mathrm{NoP}$ & H\&LC & $\begin{array}{l}\text { Preserving knowledge } \\
\text { of traditional music } \\
\text { through performing } \\
\text { practitioners. }\end{array}$ & $\begin{array}{l}\text { Experiential } \\
\text { learning }\end{array}$ \\
\hline
\end{tabular}

In Table II, for the most part, the activities that are based on Intangible Culture Heritage Empowerment (ICHE) activities that support the participatory spectrum of ColP, $\mathrm{CrP}$ and DrP are observed to be better in terms of growth towards building knowledge and education for the audience/community concerned. This is because these three forms of participation encourage active engagement, be it psychomotor or cognitive elements, rather than NoP participatory forms that only stimulate participants' cognitive features.

The participatory forms of ColP that emerge in the $\mathrm{H} \& \mathrm{~Wb}$ and VAE activity categories enhance the value of collaborative learning/education. Collaborative learning is produced through collaborative learning that promotes broader and more open communication. It will encourage higher levels of creativity and more excellent knowledge value. The building of education is too supported by activities based on local socio-cultural practice, where the values of moral education (value of cooperation, mutual assistance and mutual understanding) are completely operated.

ColP's participatory form of collaborative learning has become a vital and commonly used and extensively conferred topic for many art practitioners and researchers in this participatory arts practice. This practice is too regarded to be a trigger to the prospective for expansion and development of social and political sectors within a community [10]-[12]. Nevertheless, as being maintained by [12] it should include efficient and substantial governance applications that prompt to the finding of common ground 
between participants with apt methods and distinct vision.

While, the CrP participants who came through VAE and H\&LC based events developed an 'informal learning' perspective. This method offers a chance for the audience to expand their creativity individually with little guidance from the artist. The intangible cultural knowledge created through this informal learning method is very open, whereby the audience acts more on the value of existing knowledge and experience or knowledge produced in the location of LIAC's art heritage and local culture. The information is then materialized back into creative work, such as painting. Through the mechanism of activity under this participatory form, cultural heritage empowerment is less informal and more personal.

As a step to promote the empowerment of intangible cultural heritage, activities that have a DrP participatory spectrum are perceived as more effective and better in comparison to those under the $\mathrm{CrP}$ participatory group. It is due to this spectrum, locals (art practitioners) can share their knowledge/skills directly with outside participants in small groups. Second, the activity based on the participatory spectrum promotes the process of maximize and better communication among participants, following smaller scale and focused activities. The process of creativity can be encouraged individually (personally) in smaller divisions. This DrP spectrum based activity has the characteristics of collective learning based on the value of knowledge that is built directly through skilled people.

However, activities based on these mechanisms should be carried out through a more extended period and a more structured process to making sure that each participant has the real knowledge and skills that can continue to help them to produce this legacy that is being passed down independently without the assistance of skilled individuals.

Whereas for Intangible Culture Heritage Empowerment activities that assimilate participatory forms of NoP, the value of knowledge is built on 'experiential learning'. The audience accumulates knowledge based on the work executed by practitioners/artists through the form of performing arts-based activities. In this circumstance, the audience's knowledge value will rely highly on the power of the interaction that the practitioner/artist brings to the event.

\section{CONCLUSION}

LIAC is a community-based art project that aspires to empower local intangible cultural heritage. The ICHE is employed through its mechanism of practice that depends on the process of interaction and audience participation in activities that are formed by local cultural heritage. This participatory process prompts inclusive knowledge/education.

Inclusive knowledge is attained through the multiple forms of learning pedagogy (collaborative, collective, informal and experiential learning) that are motivated by its mechanism of activity that enhances participatory behavior. The ICH-based activity in LIAC can produce inclusive knowledge when its activation mechanism is allowed:

1. Acts as a platform for developing/exposing the talent or potential audience through drawing or artsy activities (perceived in the context of informal education).
2. Builds up cultural capital through the transfer of traditional knowledge related to local intangible cultural heritage, especially to external participants.

3. Fosters excellent social capital, where the activity acts as a connector adhering the fraternity, building partnerships and cooperation among participants and locals through collaborative participation activities.

Steps taken to design a community-based art program on an efficient basis as LIAC's art project builds its foundation on local heritage and culture is a probable offer to refresh the intangible cultural heritage of a swiftly lost society with the current of modernization. Efforts to empower this form of cultural heritage through the development of this inclusive knowledge need to be supported by:

1. Formation of activities that are genuinely localcontextual, concerning the intangible cultural heritage of the community/citizen concerned.

2. Complete and comprehensive participation among local participants/communities will develop valid knowledge and learning values.

3. The involvement of locals with knowledge and high skills related to the local cultural heritage can facilitate to broaden their knowledge and skills better.

4. The execution of effective communication in activity will extend to a more organized and comprehensive circulation of knowledge and learning.

\section{ACKNOWLEDGMENT}

This research paper is administered in partnership with PACAQ (Public Art Creative Aesthetic and Quality) University of Technology MARA, Melaka, Malaysia.

\section{REFERENCES}

1. J. Pillai, and A. Vanessa, Learning with Intangible Heritage for a Sustainable Future: Guidelines for Educators in the Asia-Pacific Region. Bangkok: UNESCO, 2015.

2. M. Y. M. Yuszaidy, Undangundangdanaktaperlindunganwarisankebudayaan di Malaysia: Satuanalisisperkembanganya. $\mathrm{PhD}$ thesis, Selangor: National University of Malaysia, 2015.

3. A. Power and S. Karen, "Heritage, health and place: The legacies of local community-based heritage conservation on social wellbeing," Health and Place, 39, 2016, pp. 160-167.

4. H. Pablo, Education for Socially Engaged Art: A Materials and Techniques Handbook. New York: Jorge Pinto Books, 2011.

5. Z. Rosli, "Model PIE dalamPasar Karat DondangSayang," in Ilham LENJO Art Exchange 2012 Jongjakarta, A. R. Haslinda, I. Diana and A. A. Anissa, Eds. Melaka: FakultiSeniLukisdanSeniRekaUiTM, 2012, pp. 8-9.

6. A. S. Brown, J. L. Novak-Leonard, and S. Gilbride, Getting in on the Act: How Arts Groups are Creating Opportunities for Active Participation. California: The James Irvine Foundation, 2011.

7. D. Hanapi, "EtosMelayu,", in AsaskebudayaandanKesenianMelayu, D. Anwar, Ed Selangor: UniversitiKebangsaan Malaysia, 2008, pp. 95 116. 
8. I. Diana, M. Y. M. Yuszaidy, Y. Yusmilayati, and Z. Rosli, "Seniberteraskankomuniti: Pemberdayaan modal sosialmelaluinilai-nilaiperpaduansosialdalam program Lendu International Art Camp. (Community-based arts: Social capital empowerment through social cohesion values in lendu international art camp program)," eBangi, 15(3), 2018, pp. 29-42.

9. N. Bourriaud, P. Simon, W. Fronza, and C. Mathieu. Relational Aesthetics. Dijon: Les Presses Du Réel, 2002.

10. O. Kelly, Community, Art and the State: Storming the Citadels. Stroud: Comedia, 1983.

\section{AUTHORS PROFILE}

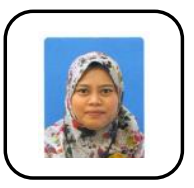

Diana Ibrahim is a senior lecturer in UniversitiTeknologi MARA, Melaka, Malaysia and currently pursuing her PhD in Faculty of Social Science and Humanities in National University of Malaysia, Bangi, Malaysia. Her expertise is fine arts and community arts. Many of her researches and publications were focusing on visual arts and participatory art practices in communitybased art programs. Diana is an active member of organizing committee for community art programs named Lendu International Art Camp (LIAC) in 2013,2014\& 2016 and participative art project called Pasar Karat DondangSayang (PKDS) that has been held 4 times in Malaysia and 3 times in Indonesia. She is also actively exhibited her visual artworks Malaysia and abroad such as UK, Germany, China and Indonesia.

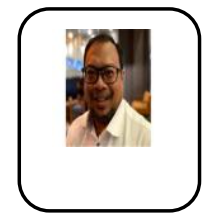

MohdYuszaidyMohdYusoff, PhD-Senior Lecture at the Malay Excellence and Sustainable Heritage Centre in Cultural and Heritage Studies, Faculty of Social Science \& Humanities, National University of Malaysia. His specialization includes Malay socio-cultural, museum management and collection and Intangible Cultural Heritage. He is also an editor for an online journal e-Bangi.

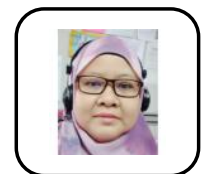

YusmilayatiYunos, $\mathrm{PhD}-$ Senior Lecture at the Malay Excellence and Sustainable Heritage Centre in Cultural and Heritage Studies, Faculty of Social Science \& Humanities, National University of Malaysia. She is an expert in traditional Malay \& Javanese medicine and Malay manuscript. She is a prolific researcher in the area of Malay herbs medicine. Yusmilayati has edited a book titled Malay Ethos and Cultural Expression (2018) published by UKM (National University of Malaysia and she is currently the editor for JurnalMelayu (UKM).

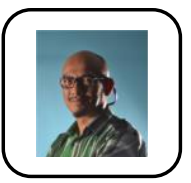

RosliZakaria has a long experience in teaching at several schools between 1986 - 2002 before became a senior lecturer at the Faculty of Art and Design, UniversitiTeknologi MARA, Melaka, Malaysia. After completed his $\mathrm{PhD}$ in 2013, he actively produced numbers of publications for his area of specialization in visual, public and community art. He is also a sculptor and has made 15 public sculptures local and abroad besides hundreds of exhibitions. Rosli often invited to art talks and forums in Malaysia. In 2013 Rosli founded Lendu International Art Camp (LIAC), an international community-based art program.

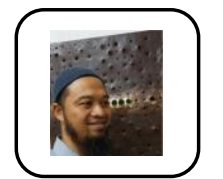

MohdSaharuddinSupar is a sculptor and an art educator. He has been producing and exhibiting artworks internationally and locally since mid-90's ranged from small table sculptures to large sculptures in public spaces. He is also participated in community/publicbased art programs named Lendu International Art Camp (LIAC) and Pasar Karat DondangSayang (PKDS), did research and wrote several papers based on those programs. Saharuddin is a senior lecturer in arts at the Faculty of Art and Design, UniversitiTeknologi MARA, Melaka, Malaysia. While juggling his artistic career and education job, he is a passionate gardener. 